\title{
MASALAH OEDIPUS COMPLEX \\ DALAM NOVEL UMIBE NO KAFUKA \\ KARYA HARUKI MURAKAMI
}

\author{
Linda Unsriana \\ Japanese Department, Faculty of Language and Culture, Bina Nusantara University, \\ Jln.Kemanggisan Ilir III No.45, Kemanggisan/Palmerah, Jakarta Barat 11480.
}

\begin{abstract}
Haruki Murakami, a Japanese novelist is an example of a great novelist who has produced his works which have been translated in various languages for a variety of readers in the world. He has also been awarded the Yomiuri Literary Award for his novel Wind-up Bird Chronicle in 1996. In his novel Umibe no Kafuka, Murakami describes the life of a young man and the Oedipus complex problems he experienced. This study will look for root causes of problems in the Oedipus complex problem of Kafka Tamura, to analyze them through methods of role characterization.
\end{abstract}

Keywords: Haruki Murakami, Umibe no Kafuka, Oedipus complex, characterization

\begin{abstract}
ABSTRAK
Haruki Murakami, seorang novelis berkebangsaan Jepang yang merupakan salah satu contoh novelis hebat yang telah menghasilkan karya-karyanya yang telah diterjemahkan dalam berbagai bahasa untuk berbagai pembaca di dunia. Ia juga pernah mendapat penghargaan Yomiuri Literary Award untuk novelnya Wind-up Bird Chronicle pada tahun 1996. Pada novelnya yang berjudul Umibe no Kafuka, Murakami menggambarkan kehidupan seorang pemuda dan masalah Oedipus complex yang dialaminya. Penelitian ini akan mencari akar permasalahan dari masalah Oedipus complek pada tokoh Kafka Tamura, dengan menganalisisnya melalui metode karakterisasi penokohan.
\end{abstract}

Kata kunci: Haruki Murakami, Umibe no Kafuka, Oedipus complex, penokohan 


\section{PENDAHULUAN}

Karya sastra adalah produk dari suatu keadaan kejiwaan dan pemikiran pengarang yang dituangkan ke dalam bentuk tertentu secara sadar dalam bentuk penciptaan karya sastra. Proses penciptaan karya sastra terjadi dalam dua tahap. Tahap pertama dalam bentuk meramu gagasan dalam situasi imajinatif dan abstrak kemudian dipindahkan ke dalam tahap kedua yaitu penulisan karya yang sifatnya mengongkritkan apa yang sebelumnya dalam bentuk abstrak. Karya sastra tidak dapat dilepaskan dari masalah penciptaan yang diikuti oleh berbagai macam masalah kejiwaan.

Sastra sebagai gejala kejiwaan di dalamya terkandung fenomena kejiwaan yang tampak lewat perilaku tokoh-tokohnya. Dengan demikian, karya sastra (teks sastra) dapat didekati dengan menggunakan pendekatan psikologis. Hal ini tentu dapat kita terima karena antara sastra dengan psikologi memiliki hubungan lintas yang bersifat tak langsung dan fungsional. Tidak langsung artinya hubungan itu ada karena baik sastra maupun psikologi kebetulan memiliki tempat berangkat yang sama yaitu kejiwaan manusia secara mendalam. Hasil penangkapan itu setelah mengalami proses pengolahan diungkapkan dalam bentuk sebuah karya sastra. Perbedaanya adalah pengarang mengemukakanya dalam bentuk formulasi penelitian psikologi. Dengan demikian tidaklah mengadaada kalau antara sastra dan psikologi dapat dilakukan kajian lintas disiplin ilmu.

Psikologi dan karya sastra memiliki hubungan fungsional, yakni sama-sama berguna untuk mempelajari keadaan kejiwaan orang lain. Perbedaanya gejala kejiwaan yang ada dalam karya sastra adalah gejala-gejala kejiwaan dari manusia imajiner sedangkan dalam psikologis manusia dalam dunia nyata. Sekalipun demikian keduanya dapat saling melengkapi dan saling mengisi untuk memperoleh pemahaman yang lebih mendalam terhadap kejiwaan manusia karena mungkin saja apa yang terungkap oleh pengarang tidak mampu diamati oleh psikolog atau bahkan sebaliknya.

Secara kategori, sastra berbeda dengan psikologi. Sastra berhubungan dengan dunia fiksi, drama, puisi, esai yang diklasifikasikan ke dalam seni (art) sedang psikologi merujuk kepada studi ilmiah tentang perilaku manusia dan proses mental. Meski berbeda keduanya mempunyai titik temu atau kesamaan, yakni keduanya berangkat dari manusia dan kehidupan sebagai sumber kajian (Siswantoro,2005:29).

Bicara tentang manusia, psikologi jelas terlibat erat, karena psikologi mempelajari perilaku. Perilaku manusia tidak lepas dari aspek kehidupan yang membungkusnya dan mewarnai perilakunya. Novel atau cerpen sebagai bagian bentuk sastra, merupakan jagad realita yang di dalamnya terjadi peristiwa dan perilaku yang dialami dan diperbuat manusia (tokoh). Realita sosial, realita psikologis, realita religius merupakan tema-tema yang sering kita dengar ketika seseorang menyoal novel sebagai realita kehidupan. Secara spesifik realita psikologis sebagai contoh, adalah kehadiran fenomena kejiwaan tertentu yang dialami tokoh utama ketika merespon atau bereaksi terhadap diri dan lingkungan. Karya sastra merekam kejiwaan yang terungkap lewat perilaku tokoh. Perilaku ini menjadi data atau fakta empiris yang harus di munculkan oleh analis, atau pembaca ataupun peneliti sastra.

Tindakan analisis psikologi dengan fokus pada perilaku tokoh, dinyatakan oleh Harjana, sebagai berikut:

Orang dapat mengamati tingkah laku tokoh-tokoh dalam sebuah roman atau drama dengan memanfaatkan pertolongan pengetahuan psikologi. Andai kata ternyata tingkah laku tokoh-tokoh tersebut sesuai dengan apa yang diketahuinya tentang jiwa manusia, maka dia telah berhasil menggunakan teori psikologi modern untuk menjelaskan dan menafsirkan karya sastra.Bila tokoh Hamlet menunjukkan tingkah laku yang kemudian oleh Freud dinyatakan sebagai ciri-ciri jenis kepribadian tertentu yang bertingkah laku tertentu di dalam lingkungan tertentu, tidaklah berarti bahwa pujangga Shakespeare mengenal teori-teori Freud, melainkan memang mempunyai pengamatan yang tajam dan mendalam tentang hakekat atau kodrat manusia(1991:66) 
Penelitian ini akan melihat sisi psikologi tokoh utama yang mengalami masalah oedipus complex.. Tokoh dalam fiksi akan disoroti secara psikologi, untuk mengetahui karakter dan masalah kejiwaan tokoh fiksi tersebut. Penelitian ini mengambil korpus data dari novel berjudul Umibe no Kafka, karya Haruki Murakami.

\section{Haruki Murakami}

Haruki Murakami, seorang novelis berkebangsaan Jepang yang merupakan salah satu contoh novelis hebat yang telah menghasilkan karya-karyanya yang telah diterjemahkan dalam berbagai bahasa untuk berbagai pembaca di dunia. Haruki Murakami lahir pada tanggal 12 Januari 1949 di Kyoto. Sejak kecil Murakami hidup dengan pengaruh budaya barat, khususnya musik dan kesusastraan. Murakami kuliah di Universitas Waseda jurusan seni teater. Kehidupan di kampus tidak begitu menarik baginya, Murakami lebih sering menghabiskan waktu membaca naskah film yang berada di museum teater Universitas Waseda. Membuka Jazz Bar "Peter Cat" dengan istrinya Yoko dari tahun 1974-1982. Novel pertamanya yang berjudul Hear the Wind Sing (Triology of Rat) pada tahun 1979, yang mendapatkan Noma Bungei Sho (Noma Literary Award) untuk penulis pendatang baru. Pada tahun 1987, ia merilis novelnya lagi yang berjudul Norweigian Wood (Noruwei no Mori). Setelah itu Januari 1991, ia pindah ke Assiociate Professor at Princeton University (Perkumpulan Profesor Universitas Princeton), dan dinobatkan sebagai professor Januari 1992. Penerimaan Yomiuri Literary Award untuk novelnya Wind-up Bird Chronicle pada tahun 1996. Penghargaan yang didapat oleh Haruki Murakami antara lain: Yomiuri Literary Prize (1995), Kuwabara Takeo Academic Award (1998), Frank O’Connor International Short Story Award (Irlandia,2006), Franz Kafka Prize (Cekoslovakia,2006) dan Asahi Prize (Japan, 2006). Terakhir dia meraih Kiriyama Prize (2007), sebuah penghargaan untuk penulis unggul di kawasan Pasifik dan Asia Selatan. Karya-karya Murakami telah diterjemahkan ke dalam lebih dari 40 bahasa.

\section{Umibe no Kafuka}

Novel Umibe no Kafuka ini menceritakan pelarian seorang anak laki-laki berumur 15 tahun bernama Kafka Tamura dari rumah ayahnya untuk melepaskan diri dari kehidupan yang dijalaninya bersama ayahnya. Ayah Kafka adalah seorang pemahat hebat, dengan kehidupan yang eksentrik, tidak biasa dari kehidupan normal dalam keluarga. Hubungannya yang buruk dengan ayahnya, dan keinginan untuk menemukan ibu kandung dan kakak perempuannya itulah yang menyebabkan Kafka kabur dari rumah ayahnya. Ibu dan kakak perempuannya meninggalkan Kafka sejak kecil. Berbagai petualangan telah dilewatinya dalam pelariannya. Pada akhirnya, Kafka menemukan dirinya pada perpustakaan pribadi di Takamatsu. Kemudian ia melamar untuk menjadi pegawai di perpustakan kecil tersebut. Di tempat kerjanya, ia bertemu dengan nona Saeki dan Oshima. Nona Saeki adalah wanita paruh baya, yang pantas menjadi ibunya. Kerinduan akan ibunya membuatnya jatuh cinta pana Nona Saeki, wanita yang lebih pantas menjadi ibunya. Hari-hari yang dilewatinya di perpustakaan itu sampai suatu hari polisi menghubungkan dirinya dengan sebuah pembunuhan seorang pemahat terkenal yaitu ayahnya sendiri,Koichi Tamura. Artikel ditulis berdasarkan studi pustaka, membaca novel Umibe no Kafuka secara detail, untuk menemukan bagian yang menjelaskan masalah Oedipus complek. Setelah data data terkumpul, lalu dianalisis menggunakan teori penokohan dan metode deskriptif analisis, untuk mendapatkan kesimpulan.

\section{PEMBAHASAN}

Penokohan adalah penyajian watak tokoh dan penciptaan citra tokoh, yang berarti tokoh-tokoh perlu menggambarkan ciri-ciri lahir dan sifat serta sikap batinnya, agar kualitas tokoh, kualitas nalar dan jiwanya dikenal oleh pembaca (Sudjiman, 1991 :18). 
Menurut Nurgiyantoro (2004: 165-166) penokohan adalah pelukisan gambaran yang jelas tentang seseorang yang ditampilkan dalam sebuah cerita. Penokohan juga mencakup masalah siapa tokoh cerita, bagaimana penempatan dan pelukisannya dalam sebuah cerita. Sehingga sanggup memberikan gambaran yang jelas kepada pembaca. Penokohan juga sekaligus menuju pada teknik perwujudan dan pengembangan tokoh dalam sebuah cerita. Masalah penokohan dalam sebuah karya tidak semata-mata hanya berhubungan dengan masalah pemilihan jenis dan perwatakan para tokoh, melainkan juga bagaimana melukiskan kehadiran dan penghadirannya secara tepat sehingga mampu menciptakan dan mendukung tujuan artistik karya yang bersangkutan (Nurgiyantoro, 2002 : 144).

Novel Umibe no Kafuka menggunakan teknik penceritaan dengan sudut pandang persona pertama"First person participant" yaitu pencerita yang ikut berperan sebagai tokoh utama, melaporkan cerita dari sudut pandang "aku", dan menjadi fokus atau pusat cerita. Tokoh "Aku" dalam novel ini bernama Kafka Tamura, anak laki-laki berusia 15 tahun, akan tetapi sudah sangat mandiri. Sejak kecil, ia sudah ditinggalkan oleh ibunya, sehingga membuatnya menjadi remaja yang sangat dewasa.

Tulisan ini akan menyoroti aspek kejiwaan yang dialami tokoh utama yang bernama Kafka Tamura dalam Novel Umibe no Kafuka (Kafka and The Shore) karya pengarang ternama Jepang Haruki Murakami.

Kafka Tamura digambarkan sebagai tokoh yang mengalami Oedipus complex. Kutipan berikut menjelaskan pada kita bahwa tokoh utama dalam novel ini mengalami Oedipus complex:

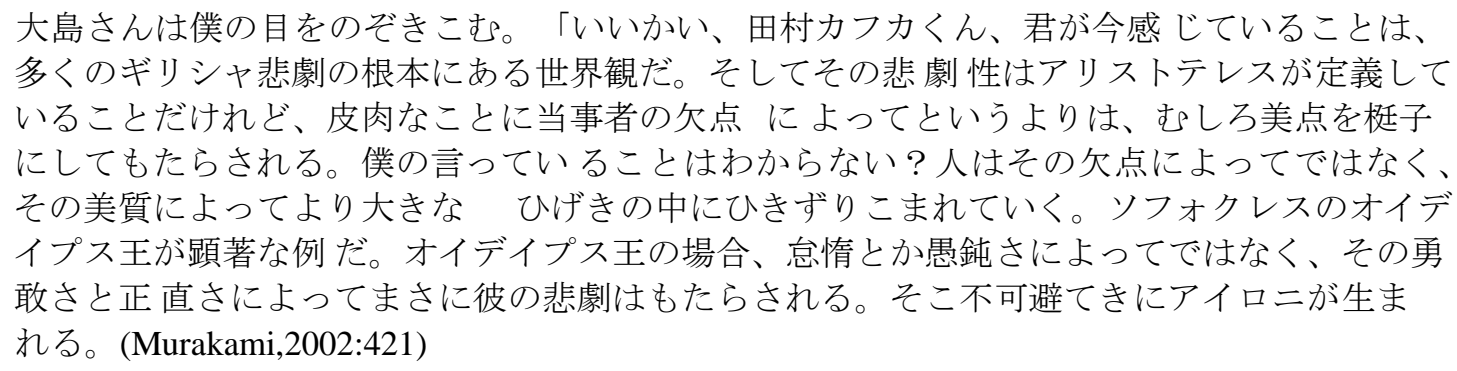

Oshima menatap mataku dalam-dalam."Dengar Kafka. Yang kau alami sekarang ini merupakan motif dari pelbagai tragedi Yunani. Manusia tidak memilih nasibnya sendiri. Nasiblah yang memilih manusia. Itu adalah dasar dari pandangan dunia terhadap drama Yunani. Dan pengertian tragedi menurut Aristoteles ironisnya, bukan berasal dari kelemahan tokoh protagonisnya melainkan dari kualitasnya yang baik. Kau tahu apa yang aku maksud? Manusia semakin jauh terbenam dalam tragedi bukan karena kekurangan mereka melainkan karena kebaikannya. Contoh yang paling bagus adakah Oidipus Rex karya Sophokles.

Menurut Freud dalam Bertens (2006:20), Oedipus Complex adalah keinginan erotis anak lakilaki yang terarah pada ibunya, sedangkan permusuhan dilontarkan kepada ayah yang dianggap sebagai saingan. Dalam hal ini Freud menggaris bawahi ambivalensi perasaan yang menyertai kompleks oidipus. Dengan ambivalensi perasaan dimaksudkannya bahwa cinta akan ibu bisa saja berbarengan dengan agresivitas, sedangkan benci terhadap ayah dapat tercampur dengan simpati.

Freud melukiskan kompleks Oidipus terutama dari sudut anak laki-laki, tetapi ia berpendapat bahwa pada pokoknya hal yang sama berlaku juga bagi anak perempuan.

Oedipus adalah tokoh mitologi Yunani yang tanpa diketahuinya membunuh ayahnya, Laius dan menikahi ibunya. Mitos ini menjadi tema karya tragedi Yunani, oedipus Tyrannos, karangan Sophokles. 

berikut:

Tokoh Kafka digambarkan tertarik pada wanita paruh baya, seperti tampak dalam kutipan 彼女は僕にとても強い、でもどことなつかしい印象を与える。この人が 僕の母親 のだと いいのにな、と僕は思う。僕は 美しい（あるいは感じのいい）中年の女の人を目にするた びにそう考えてしまう。この人が僕の母親であればいいのにと。いうまでもないことだけれ ど、佐伯さんがじっさいに僕の母親である可能性はほとんどゼロに近い。しかし、それでも、 理論的にいうなら、ほんの少しは可能性がある。なぜなら僕は母親の顔も知らないし、名前 寸ら知らないのだから。つまり彼女が僕の母親であってはならないという理由はないのだ。 (Murakami,2002:81)

Dia benar benar membuatku terkesan, membuatku merasa sedih dan penuh nostalgia. Alangkah bahagianya seandainya dia ibuku. Aku senantiasa memiliki pikiran yang sama setiap kali bertemu dengan wanita paruh baya yang cantik. Aku sadar, kemungkinan nona Saeki adalah ibuku sangat kecil. Meski demikian, karena aku tidak pernah tahu bagaimana rupa ibuku, atau bahkan namanya, maka kemungkinan itu tetap ada. Tidak ada yang benar-benar dapat mengesampingkan kemungkinan ini .

Kafka Tamura yang sejak kecil telah ditinggalkan ibunya selalu merasa sedih jika bertemu dengan wanita paruh baya. Ia membayangkan bahwa wanita paruh baya yang ditemuinya di Takamatsu adalah sosok ibunya.

Penyebab terjadinya Oedipus Complex pada tokoh Kafka Tamura, seperti yang terdapat dalam Changing Minds. Org (2011) dinyatakan bahwa:

A critical aspect of the Oedipal stage is loosening of the ties to the mother of vulnerability, dependence and intimacy. This is a natural part of the child becoming more independent and is facilitated by the realization that the mother desires more than just the child.

Tokoh Kafka mengalami ikatan yang lemah dengan ibunya. Sejak kecil ia sudah ditinggalkan oleh ibu dan kakak perempuannya.

Kutipan:

つまりお母さんはきみのお姉さんだけを連れて家を出っていったんだね。お父さんと、四歳 になったばかりの君をあとに残して」。僕は 財布の中から海 辺の写真を取り出して彼女に 見せる。「これがお姉さんだよ」。さくらさんはこの写真をしばらく眺める。そして、なに も言わず僕に返す。「そのあと、お姉さんとはまったく会っていない」と僕は言う。「母親 とも会っていない」。まった く連絡もないし、どこにいるかもわからない。どんあ顔うい していたかも思いだ せない。写真も一枚ものこっていないんだ。そこにあった匂いは 思い だせる。感触のようなものも思いだせれ。でもどう s じても顔が浮かんでこない」。 (Murakami,2002:177)

Jadi ibumu pergi dari rumah dengan kakak perempuanmu saat kau berusia empat tahun, meninggalkan kau dan ayahmu.Aku mengeluarkan foto kakakku dan aku ketika kami di pantai dari dalam dompet, serta menunjukkan padanya. "ini kakakku,"kataku. Sakura memperhatikan foto itu sebentar, kemudian mengembalikannya tanpa mengatakan apapun. Sejak itu, aku belum pernah bertemu dengan dia,"ujarku."Atau ibuku. Dia tidak pernah menghubungi, dan aku tidak tahu dimana dia berada. Aku bahkan tidak ingat wajahnya."

Lemahnya ikatan antara Kafka Tamura dan ibu kandungnya, yang telah meninggalkannya ketika Kafka Masih berusia 4 tahun menjadi salah satu sebab terjadinya oedipus complek yang dialaminya.

Selain itu, Kafka merasa tidak dicintai ibu kandungnya sendiri. Kutipan berikut akan menjelaskannya: 
Kutipan:

君のお姉さんは養女なんだよね。つまり君が生まれる前に、どこからもらわれてきた子ども なんだよね」。そうだ、と僕は言う。両親はどうしてかわから ないが、養子をとった。そ のあとで、僕が生まれた。おそらくはおもいがけず。それで君は間違いなくお父さんとお母 さんのあいだに生まれた子どもなんだね」。僕の知るかぎりでは」と僕は言う。「それなの に 君のお母さんは家を出ていくときに、君ではなく、血のつながりのないお姉さんのほう を連れていった。」とさらは言う。「でも普通、女の人というのは、そういうことはし ないものなん だよ」。僕は黙っている。「それは、どうしてなんだろう？」。僕は首を振 る。わからない、と僕は言う。それは僕が何万回となく自分自身に間違いかけた質問だった。 「でも、君は そのことでもちろん傷ついている」。(Murakami, 2002:183)

“Kakakmu anak adopsi. Mereka mendapatkannya dari suatu tempat sebelum kau lahir, kan?”. "Benar, jawabku. Aku tidak tahu kenapa tapi orang tuaku memang mengadopsi dia. Setelah itu aku lahir.

Mungkin tidak seperti yang mereka harapkan."

"Jadi kau adalah anak kandung dari ibu dan ayahmu.'

"Sejauh yang aku tahu," kataku padanya.

"Tapi, manakala ibumu meninggalkan rumah, dia tidak membawamu melainkan kakakmu, yang bukan darah dagingnya,"kata Sakura. "Bukan sesuatu yang biasanya akan dilakukan seorang wanita". Aku tidak mengatakan apapun.

“Mengapa dia melakukan hal itu?”Aku menggelengkan kepala."Aku tidak tahu,"ucapku padanya.

"Aku sendiri juga kerap bertanya pada diriku sendiri."

"Pasti sangat menyakitkan."

Kutipan lainnya juga menunjukkan perasaan Kafka yang merasa tidak dicintai ibunya:

Kutipan:

「そんなに会いたくないの?」

「会ってなにを話せばいいのかわからないし、彼女は僕になんか会いたくないかも

しれない。それはお母さんについても同じだよう。だれも僕になんか会いたがらな

いかもしれない。誰も僕のことを求めていないかもしれない。だいいち出ていって

しまったわけだし」。僕抜きで、と僕はおもう。(Murakami,2002:189)

"Apa kau tidak ingin bertemu ibumu?”

"Aku tidak tahu apa yang akan kami bicarakan, dan mungkin dia tidak mau bertemu aku. Barangkali mereka berdua tidak ingin berurusan denganku. Tidak ada satupun yang mencari aku. Maksudku, mereka pergi begitu saja.” Tanpa aku, kataku dalam hati.

Jauh di lubuk hatinya, Kafka merasa tidak dibutuhkan, tidak dicintai. Perasaan ditinggalkan itu tetap melekat hingga dia dewasa.

Menurut Freud (Bertens,2006:21), Oedipus Complex adalah keinginan erotis anak laki-laki yang terarah pada ibunya, sedangkan permusuhan dilontarkan kepada ayah yang dianggap sebagai saingan. Novel Umibe no kafka juga menguraikan ketidakcocokan antara tokoh utama dan ayahnya. Pelarianya dari rumahnya di Nogata, Tokyo, membuktikan hal itu. Kebenciannya pada ayahnya juga terlihat jelas dari kutipan berikut:

Kutipan:

「それでお父さんとはうまくいかなかったんだね?」と彼女はあとで僕に 尋㸚る。うまくい かない?いったいなんて答えればいいんだろう? 僕は何も言わず、ただ首を振る。

(Murakami,2002:178)

“Jadi, kau tidak akur dengan ayahmu?’tanyanya setelah beberapa saat. Tidak akur? Bagaimana aku harus menjawab pertanyaan itu? Aku tidak mengatakan apapun, hanya menggelengkan kepala.

"Pertanyaan bodoh-tentu saja tidak akur. Kalau ya, kau pasti tidak akan melarikan diri,"kata Sakura. 
Kafka merasa bahwa ayahnya tidak mencintainya seperti tampak pada kutipan berikut: Kutipan:

それから野方の家と、今ごろはそこにいるはずの父親のことを考える。かれは僕がとつぜん いなくなってしまったことについて、どのように感じているん だろうか。それとも戸惑っ ているのだろうか?あるいはほとんどの感情も抱かないのだろうか。いや、僕がいなくなっ たことにきがつきさえしないかもしれない。(Murakami,2002:90)

Aku berpikir tentang rumahku di Nogata, Tokyo, dan ayahku. Bagaimana perasaannya menyadari aku tiba-tiba menghilang. Mungkin lega? Bingung? Atau bahkan tidak merasa apa-apa sama sekali. Aku yakin dia bahkan tidak menyadari bahwa aku pergi.

Meskipun ia adalah anak laki-laki satu- satunya hubungannya tidak baik dengan ayahnya.

Kepergian Kafka dari rumahnya membuktikan ketidakharmonisan hubungannya dengan ayahnya. Kafka merasa tidak dipedulikan dan disayang oleh ayahnya, seperti terungkap pada kutipan di atas.

Ketika Kafka mengetahui tentang kematian ayahnya dari koran, Kafka tidak merasa sedih atau kehilangan, seperti tampak pada kutipan berikut:

Kutipan:

「もし僕の受けている印象が正しいとすれば」と大島さんは僕に尋ねれ。「お父さんが誰か に殺されても、君はそのことをとくに悲しいとも、残念だと思っていないように見える」。

「こうなって残念だとは思う。なんといっても血のつながった父親だからね。でも本当の

気持ちを言えば、むしろ残念なのは、もっと早く死んでくれなかったことだよ。そういう

のが死んだ人に対してむごい言い方だというのは、よくわかっているけど」。

(Murakami,2002:419)

“Tolong koreksi jika aku salah,"kata Oshima,"tapi kelihatannya kau tidak terlalu sedih ayahmu dibunuh."

"Tidak, tentu saja aku sedih. Bagaimanapun juga dia ayahku. Tapi yang aku sesali kenapa dia tidak meningal lebih cepat. Aku tahu itu ucapan yang sangat tidak pantas....

Kebencian terhadap ayahnya juga disebabkan sedari kecil ia merasa dipaksa untuk meyakini bahwa ia akan meniduri ibunya. Kata-kata itu seperti dipahatkan ayahnya ke dalam kepala Kafka.

Kutipan:

「予言というよりは、呪いに近いかもしれない。父は何度も何度も、それを繰り返

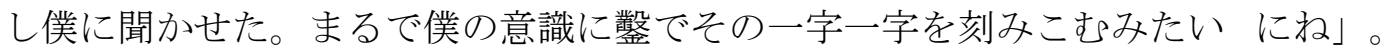

僕は深く息吸い込む。そして僕がこれから口にしなくてはならないものごとをも う一度確認する。もちろん確認するまでもなく、それはそこにある。それはいつ だってそこにある。(Murakami,2002:426)

"Menurutkutku, mungkin lebih pantas disebut kutukan ketimbang ramalan. Ayahku mengatakannya padaku berulang-ulang. Seolah-olah dia memahat setiap kata ke dalam otakku.” Aku menarik nafas panjang serta memeriksa kembali apa yang hendak aku sampaikan. Bukan karena aku memang perlu memeriksanya, karena kata-kata itu selalu ada, menghantam kepalau, tidak peduli apakah aku memeriksanya atau tidak .

Perkataan ayahnya yang berulang-ulang yang mengatakan bahwa ia akan meniduri ibunya, terasa bagai kutukan yang menimpanya.

Kafka juga membenci ayahnya karena ia juga merasa dihukum oleh ayahnya atas perbuatan ibunya yang meninggalkannya. Kafka tidak merasa diperlakukan sebagai anak, melainkan sebagai salah satu patung karya ayahnya. 
Kutipan:

「僕はどんなに手を尽くしておのも運命から逃げれることはできない、と父は言った。その 予言は時限装置みたいに僕の遺伝子の中に埋めこまれていて、なにをしようとそれを変更 することはできないんだって。僕は父を殺し、母と姉と交わる。」

大島さんは まだ長い沈黙にいる。彼は僕の言葉をひとつひとつ検証し,そこになにかの手 がかりを見いだそうとしているようだ。彼は言う、「いったいどうして、君のお父さんは 君に向かってそんなひどい予言をしなくてはならなかったんだろう?」「僕にはわからな い。父はそれ以上なにも説明しなかったから ね」。僕は 首を振る。「あるいは、自分を 捨てて出ていった母と姉に復售をしたがったのかもしれない。彼女たちを罰したかったの かもしれない。僕という左右通して」「たとえそうすることによって、君が損なわれてし まったとしても」

僕はうなずく。「僕は父にとってたぶんひとつの作品のようなものに過ぎな いんだ。彫 刻と同じだよ。たとえ壊しても損なっても、それは父の自由なんだ」。

(Murakami,2002:427)

"Ayahku berkata tidak ada yang dapat aku lakukan untuk lari dari garis nasib ini. Ramalan tersebut seperti pengatur waktu yang terkubur di dalam sifatku, dan tidak ada yang dapat mengubahnya.Aku akan membunuh ayahku dan "tinggal" dengan ibu dan kakakku.

Oshima terdiam beberapa saat, seolah-olah sedang menyelidiki setiap kata yang aku ucapkan, satu persatu, mempelajarinya untuk mencari petunjuk apa maksud dari semua ini."Untuk apa ayahmu mengatakan semua ini padamu?"akhirnya dia bertanya.

"Aku tidak tahu. Dia samasekali tidak menjelaskan,"kataku."Mungkin ia ingin balas dendam tehadap istri dan anak perempuannya yang meninggalkan dia.Mungkin ia ingin menghukum mereka melalui $a k u$.

"Walaupun itu berarti melukaimu?"

Aku mengangguk. "Bagi ayahku, barangkali aku tidak lebih dari salah satu patung- patungnya. Sesuatu yang dapat dia buat dan hancurkan bila dia ingin."

Hubungan yang tidak harmonis antara Kafka dan ayahnya, dan juga perasaan ditinggalkan oleh ibu dan kakaknya menjadi proses terbentuknya sikap dan karakter tokoh utama dalan Umibe no Kafka ini.

\section{SIMPULAN}

Tokoh utama dalam novel ini mengalami masalah Oedipus complek, mencintai dan berhubungan dengan Nona Saeki, wanita paruh baya, yang jauh lebih tua dari dirinya. Nona Saeki dibayangkannya sebagai ibu kandungnya yang pergi meninggaklan dirinya di usia masih sangat belia, yaitu ketika ia berusia 4 tahun. Pada novel Umibe no Kafka, terlihat masalah oedipus yang dialami tokoh utama disebabkan beberapa hal, yaitu hubungan yang tidak akrab dengan ibunya yang telah meninggalkannya selagi ia masih kecil, hubungan yang buruk dengan ayahnya yang dirasakan tokoh utama, bahwa ayahnya tidak pernah mencintainya sebagai seorang anak, dan hanya menganggapnya sebagai patung salah satu hasil karyanya. 


\section{DAFTAR PUSTAKA}

Bertens,K. (2006). Psikoanalisis Sigmund Freud. Jakarta: Gramedia Pustaka Utama.

Changing Minds. Org. (n.d). Oedipus complex. Diunduh 7 Maret 2010 dari http://changingminds.org/disciplines/psychoanalysis/concepts/oedipus_complex.htm

Endaswara, S. 2008. Metode Penelitian Psikologi Sastra: Teori, Langkah, dan Penerapannya. Yogyakarta: Medpres.

Feist , G. J., \& Feist, J. (2008). Theories of Personality. Yogyakarta: Pustaka Pelajar.

Hardjana, A. (1991). Kritik Sastra: Sebuah Pengantar. Jakarta: Gramedia Pustaka Utama.

Minderop, A. (2005). Metode Karakterisasi Telaah Fiksi. Jakarta: Yayasan Obor.

Murakami, H. (2008). Kafka on The Shore. Jakarta: Pustaka Alvabet.

Murakami, H. (2002). Umibe no Kafuka. Tokyo: Shinchousha.

Ratna, N. K. (2004). Teori, Metode, dan Teknik Penelitian Sastra., Yogyakarta: Pustaka Pelajar.

Siswantoro. (2005). Metode Penelitian Sastra: Analisis Psikologis. Surakarta: Muhammadiyah University Press. 